\title{
ESP Learners' Needs Related Learning for the Workplace: A Pragmatic Study for Business School
}

\author{
Hussain Ahmed Liton \\ Lecturer, English Language Centre, Jazan University, Jazan, Saudi Arabia \\ husal@jazanu.edu.sa
}

Typically, an ESP course is designed to develop students' communication skills not solely for the office, but also for useful in a specific workplace. Unfortunately, ESP for Schools of Business at some South-East Asian universities is not being very effective in promoting students' performance in the workplace. Behind this backdrop, this paper explores learners' pragmatic workplace learning practices that impact on their profession and have immediate applicability to their professional responsibilities. This article, in other words, addresses the gaps between what students learn in ESP class and what they need in real workplace. The data were collected through questionnaires from 30 ESP teachers. The data were analysed both qualitatively and quantitatively. The research results revealed that the current ESP in use fails to capture the learners' needs and skills in workplace communication. It, therefore, suggests that ESP textbook has to adapt the practical workplace needs related materials as well as supplementing extra materials through teachers' constant 'needs analysis'.

Key Words: pragmatic, needs analysis, Business Studies, workplace, effective intercultural communication

\section{INTRODUCTION}

It is commonly a difficult task to find the right and the most comprehensive range of English for Business School and ESP course materials to suit a range of students' needs in the workplace. Whether students are at work or still studying, this paper talks about issues concerning the language, skills, and additional resources they need to progress in their future career. Since the workplace is evolving globally more than ever owing to economic globalization, students and professionals need appropriate and relevant English to communicate effectively in a variety of business situations. Here lies the question of needs analysis to equip students for the journey towards their future career. To this end, ESP courses should comprise communication skills not solely for the office, but also for the use in specific workplace, such as factory, hotel, laboratory or corporate organization. Actually, teaching ESP is to fulfil the specific needs and sustainable competency of the students. English for Specific Purposes (ESP) has its driving and defining characteristic stance leading to focus on the learners' specific objectives, or 
needs to learn English for pragmatic use in a specific context. Consequently, ESP course is to be designed to meet the specific learning needs of a specific learner or group of learners within a specific time frame for which instruction in traditional General English (GE) will not suffice. This course instruction, in general, involves in orientation to specifically spoken and written English skills development to carry out specific academic or workplace tasks and purposes. Behind this backdrop, the present paper discusses learners' needs related learning for the workplace with a view to developing an effective and practical ESP for the students of Business School at some universities of South-East Asia.

In other words, this study investigates learners' needs specifying to meet those needs in actual teaching and learning situations, catering their better performance in the real workplace situation. Learners' needs will have to be addressed if the course is to be effective and successful. Business Studies students have specific English needs. This reality has developed a variety of ESP course designs. In such a context teachers' role is a vital factor as Schleppegrell defines 'Their (Teachers') task is to analyze students' needs, outline objectives, select and adapt teaching materials, design lessons, create an adult-oriented learning environment, and assess students' progress" (Schleppegrell, 1991, pp. 18-22). It underlines the issue of needs analysis.

\section{REVIEW OF LITERATURE}

In South-East Asian context, available research in the field of workplace needs related practical ESP for Business School is very rare. Globally, in the vicinity of ESP teachinglearning development, researchers have attempted to contribute available insight into the matter. This paper looks into the relevant available research information on this issue across the globe.

TESP determines to teach English in context related to students' skills need for their job in real work situations. ESP has always been with needs analysis and preparing learners to communicate effectively in the tasks prescribed by their field of study or work situation. In this regard, it is important to cite according to Hutchinson and Waters (1987) "ESP as an approach to language teaching in which all decisions as to content and method are based on the learner's reason for learning" ( p.19). Strevens (1988) described it (ESP) as English language teaching which is designed to meet specified needs of the learner (as cited in Tsao, 2011). In reality, the research and the assessment of ESP course effectiveness showed that ESP is more effective to develop learners' calibre in English. Pertaining to this, Chen (1993) points out, “...ESP is more effective in increasing students' learning motivation because it relates to their fields of study and caters to their needs" (as cited inTsao, 2011). So, ESP should properly be seen not as any particular language product but as an approach to language teaching-learning which is directed by specific reasons for learning.

Needs analysis is very important to ensure suitable and quality textbook for the ESP learners of any discipline at any context. Referring to this, Bouzidi in his research in Moroccan context spells out that the suitability of a textbook already in use is 
determined and "accomplished by a needs analysis that documents the type of workplace” (Bouzidi, 2009).

In case of ESP for Business Studies, ESP practitioners should analyze how the learners can develop effective communication skills in business dealings, conferences, negotiations and job interviews. Importantly to mention here, the ESP instructor has "...five key roles to perform: teacher, course designer and material provider, collaborator, researcher, and evaluator...." (Dudley-Evans \& St. John, 1998). Nunan (1993) rightly claims, "Needs analysis is one of the elements that distinguish traditional views of language learning and teaching from the communicative perspective towards the issues" (as cited in Rajabi \& Azarpour, 2011). Practically, it is imperative to recognize and rectify the mismatch for effective teaching-learning through the correlation between what students learn in classroom and what needs of local/international employers.

Apparently, the diverse information reflects that ESP teaching-learning is directed by a kind of students' academic and professional needs related analysis. Richards (1984) spells out that 'Needs analysis' may be used as a means of getting wider input into the "content, design, and implementation of a language programme... defining goals, objectives, and content; ...evaluating a current programme" (as cited in Nunan, 1988). Referring to this, Long (2005) cites four reasons for performing needs analyses: "First, to determine the relevance of the material to the learners' situations; second, to justify the material in terms of relevance for all parties concerned (teacher, learner, administration, parents); third, to account for differences in learner needs and styles, fourth, to create a syllabus which will meet the needs of the learners as fully as possible within the context of the situation" (Long, 2005).

Accordingly, in doing needs analysis, teachers can explore a variety "...of factual information about learners, their use of language in real life communicative situations as well as their current language proficiency and language difficulties" (Brindley, 1989, p. 70).

In today's globalised business contexts, people communicate through speaking English. That's why; this research has laid emphasis more on students' speaking and participation, but not teacher lecture as in traditional English classes. Students, in Business English classes, need to expose near to global business matters pertaining to relevant topics such as- presentations, meetings, business-affairs across cultures, advertising, marketing and many others. Cleland (1999, p.391) defines "Communication is the process by which information is exchanged between individuals through a common system of symbols, signs, or behaviour" ( as cited in Saqlain, Qazi, \& Simon, 2012). So, considering employers and employees' need, ESP for Business Studies is necessary to develop students' Business communication skills that can enhance professional performance and create new career opportunities.

Learners' specific needs analysis is a matter of fact in order to design ESP curriculum and effective pedagogy. Regarding students' need related teaching and learning, linguist experts and researchers opine that “....all learning activities are filtered through students' 
motivation" (Liton, 2012). English language is significantly important in almost every area of discipline especially in this globalised era where communications among individuals all over the world are borderless and through a variety of channels. With the globalization of trade and economy and the continuing increase of international communication in various fields, the demand for "English for Specific Purposes (ESP) is expanding, especially in countries where English is taught as a foreign language (Gao, 2007)...Dominant areas in ESP are now Business English and English for Academic Purposes (EAP) and course design issues need to take into account the target learning needs of ESP students" (Kaur \& Khan, 2010, pp. 1-16).

Esteban and Marios (2002) reflect in their study that “...the ESP teacher's task is to define students' learning needs and assume the role of language consultant, while the content teacher is the provider of what Dudley-Evans \& St John (1998) term carrier content, as well as of professional skills consultant in different situations" (Esteban \& Marios, 2002, pp. 7-21).

Very often it is found that there is a gulf between the content of ESP textbooks and actual workplace needs and demands. So, through needs analysis, ESP teachers can judge the distance between classroom material and the requirements of the workplace and be able to bridge that gap" (Bouzidi, 2009). So, undeniably authentic textbook is a highly significant factor to develop effective teaching-learning practices in the real life situation and to fulfil the employee's needs in the workplace, "a careful and wise selection of materials focused on learners is a must if we want a positive response from them" (Lee, 1995, pp. 323-328). Mishan (2005) argue that learners' interests and needs are the most important factors in the choice of authentic texts.

Seemingly, this aspect of the related literature review underpins the significance and value of the current study.

\section{METHOD}

\section{Research Context and Participants}

The study was conducted among ESP instructors who were teaching English for Business Administration at different universities in South-East Asia. This paper aims to facilitate developing "in students a relatively high level of competence in reading, and an intermediate level of competence in listening, speaking, writing, and translating so that students can communicate in English" in real life situation (Team, 1999, p. 01).

The participants of this study were chosen on a random basis. A total of 30 ESP teachers took part in this study. We took in our purview some universities like Universiti Sains Malaysia, Penang, Bangladesh Islami University (BIU), Dhaka, University of Panjab, Pakistan, Sana'a University, Yemen, Kuwait University, Kuwait and Jazan University, Saudi Arabia. Presumably and seemingly, this survey will underscore a clearer view of the overall standard of ESP courses and reflect the learners' real needs for future employment.

\section{Data Collection \& Questionnaire}


The methodology of this research maintains both quantitative and qualitative approaches. The mechanism of data collection for this study encompasses a one page written research questionnaire (See Appendix 1). The researcher sent questionnaire to 36 ESP teachers via e-mail, Facebook and Skype between January and February 2013. There were multiple choice questions as well as question asking for short suggestions, offering the respondents a free rein. The pedagogical goal of the survey was explained in the appendix, and asked the participants to answer the questions. They answered the questionnaire quite willingly, and most of them made some valuable suggestions. The questionnaire for this research quests for teachers' evaluations and suggestions about ESP learners' needs related learning for their future workplace. Importantly, this research type is useful as

"personal reflections are integral to the emerging analysis of a cultural group, because they provide the researcher with new vantage points and with opportunities to make the strange familiar and the familiar strange" (Marshall \& Rossman, 2006, p. 100).

Out of 36, a total of 30 questionnaires were returned representing a response rate of $83 \%$.

\section{RESULTS}

\section{Data Analysis}

The data of the questionnaire were analysed qualitatively and quantitatively in order, "to stress the unique strengths of the genre for research that is exploratory or descriptive" (Marshall \& Rossman, 2006, p. 60). The collected data of the questionnaire were sorted out, and the percentage of teachers offering the same answer was computed. The questionnaires were tabulated to record the responses from each participant for each option of the questions. Typically, throughout the data analysis processes, according to Creswell, the researchers "seek to identify and describe patterns and themes from the perspective of the participant(s), then attempt to understand and explain these patterns and themes" (Creswell, 2003, p. 203). Tables are drawn below to sum up the frequency of responses to almost all the questions (See Tables).

In the first question, the respondents were asked, "Does the textbook cover the situations learners are likely to encounter in their future professional environment?" $10 \%$ of the respondents answered "Yes" while 70\% of them answered "No". $20 \%$ of the respondents chose, the "Partially" option (See Table 1).

Table 1: Does the textbook cover the situations learners are likely to encounter in their future professional environment?

\begin{tabular}{lll}
\hline Choices & Answer & Percentage (\%) \\
\hline Yes & 03 & 10 \\
\hline No & 21 & 70 \\
\hline Partially & 06 & 20 \\
\hline
\end{tabular}

The majority of the teachers report that current ESP course in use does not address the situational lessons related to future professional environment. It is anticipated that 
irrespectively the participants are very much concern about effective teaching-learning game which sounds positive reaction. So, while preparing the content for a course, the course designers must draw up an inventory of topics and situations that are relevant to students' needs and are likely to motivate learning.

The $2^{\text {nd }}$ question asked the teachers, "Do you think ESP course properly addresses the needs of the Business department's students whom you are teaching?" In answer to this question $27 \%$ of the participants answered "Yes", while $43 \%$ of them replied "No" and $30 \%$ for the "partially" option. (See Table 2)

Table 2: Do you think ESP course properly addresses the needs of the Business School students whom you are teaching?

\begin{tabular}{lll}
\hline Choices & Answer & Percentage (\%) \\
\hline Yes & 08 & 27 \\
\hline No & 13 & 43 \\
\hline Partially & 09 & 30 \\
\hline
\end{tabular}

The response of a large portion (43\%) of the teachers highlights more on unsuitability of the ESP course design. Here, the positive response (27\%) avows the appropriateness of course design in a miniature scale. Considerably, the overall response suggests redesigning the ESP course in keeping with learners' future workplace needs.

The $3^{\text {rd }}$ question seeks to identify the range of suitability of the contents of existing ESP course for learner-centred practice oriented for better learning outcomes. $10 \%$ of the participants selected "Yes, Completely" option while $63 \%$ of them made a choice "No" and 27\% for the "Partially" option (See Table 3).

Table 3: Does the text material lay emphasis more on learner-centred than teachercentred approach for better learning outcome?

\begin{tabular}{llll}
\hline Choices & Answer & Percentage (\%) \\
\hline Yes, Completely & 03 & 10 \\
\hline No & 19 & 63 \\
\hline Partially & 08 & 27 \\
\hline
\end{tabular}

The response of a vast number of the respondents draws attention to the fact that the contents of existing ESP text are not wholly learner-centred and task-based practice oriented. On the other hand, the presence of positive response for the 'complete' and 'partial' suitability of the course curriculum underscores a subtle line that any curriculum design and policy needs to be adequately scrutinized to ensure students' real needs in the workplace.

In the $4^{\text {th }}$ question, the respondents were asked, "Does the course develop your students' communication skills (e.g., speaking and writing skill)?" In terms of the three choices: $10 \%$ of the participants chose "Completely" option; 30\% "Partially" option and $60 \%$ answered in the negative (See Table 4). 
Table 4: Does the course develop your students' communication skills (e.g., speaking and writing skill)?

\begin{tabular}{lll}
\hline Choices & Answer & Percentage (\%) \\
\hline Completely & 03 & 10 \\
\hline Partially & 09 & 30 \\
\hline Not at all & 18 & 60
\end{tabular}

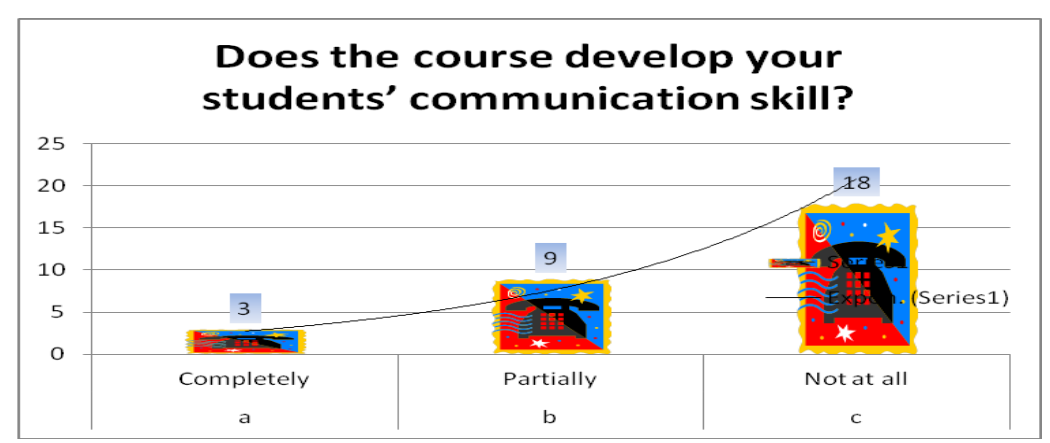

Figure 1: Communication skill

The answers to this question demonstrated nuance of expressions, and perceptions about learners' progress in communicative skills like Speaking and Writing. It showed partial advancement of learners in communication skill, but a notable portion $(60 \%)$ of them observed a sheer disappointment in the required field of competence. This impression underscored the unsuitability of textual material which does not capture the learners' appropriate need and demand. So, it subtly manifests that existing ESP textbook is not tailored appropriately according to the students' needs in the workplace.

The $5^{\text {th }}$ question sought to elicit the teachers' opinion on the use of functional and technical terms related to Business as if the learners can use those in their future professional settings. 87\% selected "Yes" while 13\% selected "Partially" option (See Table 5).

Table 5: Do you think the ESP text should cover the functional language (terms related to Business) learners are likely to use in their future professional environment?

\begin{tabular}{lll}
\hline Choices & Answer & Percentage (\%) \\
\hline Yes & 26 & 87 \\
\hline Not at all & 00 & 00 \\
\hline Partially & 04 & 13 \\
\hline
\end{tabular}

The overwhelming responses of the participants showed their awareness of ESP teaching-learning norms and forms. This course is designed to improve the learners' 
competence in particular communicative skills as well as to determine their specific skills related to workplace demand. Accordingly, it is suggested that ESP course should cover technical terms and terminologies related to Business Studies, for example, Profit $\&$ Loss account, Gross/ Net Profit, Schedule, Bill of Exchange, Balancing, Balance sheet, Debit/ Credit and the like.

Finally, the $6^{\text {th }}$ question offered a 'free will' to the participants to give more comments for formulating an effective and pragmatic ESP course. The participants' suggestions were reported into structured answers. 77\% respondents suggested that ESP course curriculum should be redesigned in keeping with the learners' needs in the workplace. 83\% participants laid emphasis more on listening, speaking, and writing skills respectively to secure communicative competence as if the learners can develop borderless communication as $21^{\text {st }}$ century skill. $80 \%$ of the respondents pointed out that Information and Communication Technology (ICT) needs to be integrated into ESP teaching which marks as a step ahead of teaching effectiveness. Interestingly, 73\% participants suggested a very ground-breaking and effective implication that the ESP learners should be exposed to the opportunity to video-led lessons related to a variety of business professions which are likely to motivate learning (See Table 6).

Table 6: ESP teachers' reflections from data analyses

\begin{tabular}{llll}
\hline Sl. No & Suggestions & Answer & Percentage (\%) \\
\hline 1. & $\begin{array}{l}\text { More practical ESP curriculum to be redesigned in } \\
\text { keeping with the learners' needs in the workplace and } \\
\text { demand of the corporate job market }\end{array}$ & 77 \\
\hline 2. & $\begin{array}{l}\text { ICT Integration in ESP classroom - a step ahead of } \\
\text { teaching effectiveness }\end{array}$ & 80 \\
\hline 3. & $\begin{array}{l}\text { The learner should be exposed to video-led lessons } \\
\text { related to variety of business professions }\end{array}$ & 73 \\
\hline 4. & $\begin{array}{l}\text { More emphasis on listening, speaking, and writing } \\
\text { skills } 25\end{array}$ & 83 \\
\hline 5. & $\begin{array}{l}\text { Teaching students to communicate confidently across } \\
\text { countries and cultures in a range of business situations }\end{array}$ & 67 \\
\hline
\end{tabular}

\section{Source: data analysis of questionnaires}

Indeed, the varied suggestions from the majority of the participants recall that the promising ESP practitioners were concerned with the upshot of their students' needs in the real life situation. Predominantly, the teachers $(83 \%)$ underlined that listening, speaking and writing skills should be given high importance to develop communicative competence which is the main concern of workplace.

\section{DISCUSSION}

This paper examined the diverse information on workplace 'needs' related ESP teaching-learning issues for business studies based on statistical data analyses and revealed the following points of propositions: 


\section{(A). Problem issues:}

\section{Unsuitability of course design}

(60-65) \% teachers' responses underlined the fact that the contents of existing ESP text are not wholly learner-centred and task-based practice oriented and it is not tailored appropriately according to the students' needs in the workplace (Tables no. $3 \& 4$ ).

\section{Irrelevant Course Materials}

The current ESP course in use does not address the situational lessons related to future professional environment (70\%, Table- 01$)$.

\section{Interactive Communication Skill ignored}

The current textual material fails to capture the learners' essential skill like communication competency which is the appropriate need and demand of the workplace.

\section{More teacher-centred than learner-centred approach}

ESP class is more teacher-centred than learner-centred because text materials are not learner-centred and task-based practice oriented.

\section{(B). Viable suggestions}

This paper divulges some viable suggestions for making a pragmatic ESP course to meet students' workplace needs.

\section{Pragmatic Course Design}

While preparing the contents of an ESP course for School of Business, the course designers must lay emphasis on topics and situations that are relevant to students' needs to carry out the basic communicative tasks required in the Business and corporate organization.

\section{Steps to Success}

The textbook should be facilitated with DVD series of effective phone calls, teleconference, or business negotiations to develop students' listening and speaking skills. It provides chances to the students to know how to take part effectively in a teleconference, a negotiation or a job interview. In this way, they build up the language and skills they need to communicate in the workplace and business situations.

\section{Cross-border communication practices}

In the textbook, there should be some options for practices in the form of writing messages, ordering and queries, sending information from one farm/country to another farm/country, or some reading passages in such forms. So, it is important to expose students to communicate confidently across countries and cultures using international Standard English in a range of business situations. 


\section{Watch \& Learn}

Video-led lessons of successful Meetings and Presentations are to be conducted in highly technology facilitated classrooms. It allows students to watch and analyse the skills in action and progress.

Information and Communication Technology (ICT) Integration: ICT integration into ESP teaching-learning will be a step ahead of teaching effectiveness.

\section{Inclusion of Business terminologies}

Additionally, ESP course should be facilitated with the opportunity to learn the technical terms and terminologies related to Business Studies (such as- Debit/ Credit, share issue, balance sheet, cost and liability etc.) as if students can use those in their future professional environment.

\section{Variables:}

Supplementing the textbook with extra materials: Using the textbook as the sole instructional guide, from cover to cover without any supplemental material, will not address the realities of individual learning situations. By providing the real needs of learners and the requirements of the workplace, ESP practitioners can bridge the gap and produce the future potential professionals.

\section{CONCLUSION}

The current study divulges certain effective implications emerging from the survey results and analyses. First, pragmatic ESP course should be redesigned in keeping with learners' future workplace needs with special emphasis on communication skills like listening, speaking and writing. Secondly, the textbook should be facilitated with DVD series of effective phone calls, teleconference, or business negotiations in order to build up students' communication skills in the workplace and business situations. Thirdly, the learner-centred task-based communicative approach should be adopted as a mode of teaching in the ESP classroom. Fourthly, for effective teaching, ICT (e.g., audio, video, internet or art movies) integration into ESP teaching-learning should be a paramount focus as a demand of the time. Finally, it can be suggested to supplement the textbook with extra materials through continuous practice of learners' needs analysis in order to expose them nearer to workplace needs and performance. After all these adaptations and conversions, it will open up a tunnel of hope for an effective workplace needs related pragmatic ESP course for Business studies. Indeed, the present paper will continue to provide very important information to the ESP professionals, course designers and students of Business studies for effective ESP teaching-learning in any TEFL situation.

\section{Acknowledgement}

This is a substantially revised version of a paper presented at the $\mathbf{5}^{\text {th }}$ International

Language Learning Conference $2013\left(5^{\text {th }}\right.$ ILLC 2013) dated from 11 November to 13 November 2013 in Universiti Sains Malaysia, Penang, Malaysia. The author of this 
study expresses his thanks to Jazan University, Jazan, Saudi Arabia for financial support to join the Conference.

\section{REFERENCES}

Bouzidi, H. (2009). Between the ESP Classroom and the Workplace: Bridging the Gap. English Teaching Forum (Number 3), 10-19.

Brindley, G. (1989). The role of needs analysis in adult ESL programme design: The second language curriculum. (R. K. Johnson, Ed.) New York: Cambridge University Press.

Creswell, J. W. (2003). Research Design: Qualitative, Quantitative, and Mixed Approaches. Second Revised ed. London: Sage Publications Ltd.

Dudley-Evans, T., \& St. John, M. (1998). Developments in ESP: A multi-disciplinary approach. Cambridge: Cambridge University Press.

Esteban, A. A., \& Marios, M. V. (2002). A Case Study of Collaboration Among the ESP Practitioner,the Content Teacher, and the Students. Revista Alicantina de Estudios Ingleses , 15, 7-21.

Hutchinson, T., \& Waters, A. (1987). English for specific purposes: A learning-centred approach. Cambridge: Cambridge University Press.

Kaur, S., \& Khan, A. M. (2010). Language Needs Analysis of Art and Design Students: Considerations for ESP Course Design. ESP World, Volume 9 (Issue 2 (28)), 1-16.

Lee, W. (1995). Authenticity revisited: text authenticity and learner authenticity. ELT Journal , 49 (4), 323-328.

Liton, H. A. (2012). Developing Efl Teaching And Learning Practices In Saudi Colleges: A Review. International Journal of Instruction, Vol.5 ( No.2), 129-152.

Long, M. (2005). A rationale for needs analysis research: Second language needs analysis. (M. H. Long, Ed.) Cambridge: Cambridge University Press.

Marshall, C., \& Rossman, G. B. (2006). Designing Qualitative Research. London: Sage Publications Ltd. (Inc 1st pub. 1989).

Mishan, F. (2005). Designing authenticity into language learning materials. Bristol: Intelect Ltd.

Nunan, D. (1988). The learner-centered curriculum: A study in second language teaching. Cambridge: Cambridge University Press.

Rajabi, P., \& Azarpour, N. (2011). Academic needs of Iranian business administration students in ESP classes. Contemporary Online Language Education Journal , 1, 20-32.

Saqlain, N. -u., Qazi, W., \& Simon, H. C. (2012). Effect of Teaching Methodologies for Business Communication at BBA Level in a Pakistani Classroom. European Journal of Scientific Research, Vol.71 (No.1), 72-77. 
Schleppegrell, M. J. (1991). English for Speciflc Purposes: a program design model. English Teaching Forum , 29 (4), 18-22.

Team, C. E. (1999). College English teaching syllabus (For regular college students). Shanghai: Shanghai Foreign Language Education Press \& Higher Education Press.

Tsao, C. H. (2011). English for Specific Purposes in the EFL Context: A Survey of Student and Faculty Perceptions. The Asian ESP Journal, 7- 2, 126-149.

\section{Appendix 1}

Dear ESP Practitioners, I have undertaken a research under the caption "ESP Learners' Needs Related Learning for the Workplace: A Pragmatic Study for School of Business". Teachers' perceptions, reflections and suggestions are highly important to make teaching materials more practical to students' needs and professional practices. Survey data will be used only for research purpose. Therefore, you are requested to answer all the questions below carefully. I appreciate your cooperation with thanks.

Hussain Ahmed Liton, Lecturer, English Language Centre, Jazan University

\section{Teachers' Questionnaire}

1. Does the textbook cover the situations that learners are likely to encounter in their future professional environment?
a) Yes
b) No
c) Partially

2. Do you think the ESP course properly addresses the needs of the Business School students whom you are teaching?
a) Yes
b) No
c) Partially

3. Does the text material lay emphasis more on learner centred than teacher centred approach for better learning outcome?
a) Yes, completely
b) No
c) Partially

4. Does the course develop your students' communication skills (e.g., speaking and writing skills)?
a) Completely
b) Partially
c) Not at all

5. Do you think the ESP text should cover the functional language (terms related to Business) that learners are likely to use in their future professional environment?
a) Yes
b) Not at all
c) Partially

6. Do you have any suggestions that may fulfil ESP learners' needs? If so, please mention here: 


\section{Turkish Abstract}

Özel amaçıı İngilizce Öğrenen Öğrencilerin İş Yeriyle İlgili Öğrenmedeki İhtiyaçları: İşletme Okulları İçin Pragmatik Bir Çalışma

Özel amaçlı bir İngilizce dersi öğrencilerin iletişim becerilerini sadece ofis için değil aynı zamanda spesifik iş ortamları için de tasarlanmıştır. Ne yazık ki Güneydoğu Asya üniversitelerinde bu dersler öğrencilerin performanslarını artırmaları için çok etkili olmamaktadır. $\mathrm{Bu}$ durumun arka planında, bu çalışma öğrencilerin işlerinde performanslarını etkileyen ve sorumlulukları üzerinde anlık uygulanabilirliği olan işyerinde pragmatik öğrenme pratiklerini incelemektedir. Bir diğer deyişle bu çalışma öğrencilerin bu derslerde ne öğrendikleriyle gerçekte neye ihtiyaç duydukları arasındaki farklı incelemektedir. Veriler 30 İngilizce öğretmeninden anket yoluyla toplanmıştır. Veriler nicel ve nitel olarak analiz edilmiştir. Araştırmanın sonuçları bu derslerin öğrencilerin ihtiyaçlarını ve iş yeri iletişimindeki becerilerini kapsamadığını göstermiștir. Sonuç olarak, öğretmenlerin yapacağı ihtiyaç analizi doğrultusunda extra materyaller sağlamanın yanında, bu derslerde işyerindeki ihtiyaçlar doğrultusunda kitapların düzenlenmesi önerilmiştir.

Anahtar Kelimeler: Pragmatic, ihtiyaç analiz, işletme çalışmaları, işyeri, etkili kültürlerarası iletişim

\section{French Abstract}

Les Besoins d'ESP Apprenants Apprentissage Lié pour le Lieu de travail : une Étude Pragmatique pour École de Commerce

Typiquement le cours ESP est conçu pour développer les compétences de communication des étudiants non seulement pour le bureau(les fonctions), mais aussi pour utile dans un lieu de travail spécifique. Malheureusement, ESP pour les Écoles d'Affaire à quelques universités Asiatiques "le Sud-est" n'est pas très effectif dans la promotion de la performance des étudiants dans le lieu de travail. Derrière ce fond, ce papier(journal) explore les pratiques d'apprentissage de lieu de travail pragmatiques des apprenants qui ont un impact sur leur profession et ont l'applicabilité immédiate à leurs responsabilités professionnelles. Cet article, autrement dit, adresse les écarts entre ce que les étudiants apprennent dans la classe ESP et de quoi ils ont besoin dans le lieu de travail réel. Les données ont été rassemblées par des questionnaires de 30 des professeurs ESP. Les données ont été analysées tant qualitativement que quantitativement. Les résultats de recherche ont révélé que le courant ESP dans l'utilisation échoue à capturer les besoins des apprenants et des compétences dans la communication de lieu de travail. Il, donc, suggère que le manuel ESP doive adapter les besoins de lieu de travail pratiques des matériels(matières) liés aussi bien que le complètement de matériels supplémentaires par les professeurs constant ' l'analyse de besoins'.

Mots Clés: pragmatique, a besoin de l'analyse, des Études commerciales, le lieu de travail, la communication interculturelle effective (efficace) 


\section{Arabic Abstract}

\section{احتياجات المتعلمين ESP التعلم متعلق لمكان العمل : دراسة عملية لكلية إدارة الأعمال}

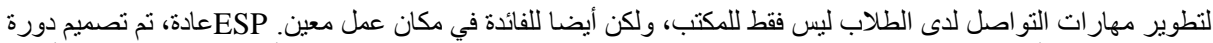

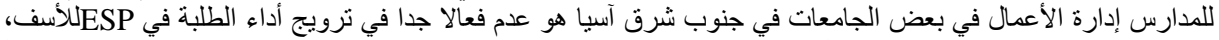

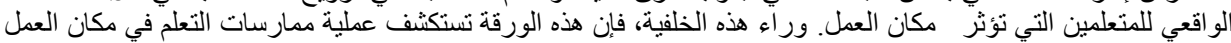

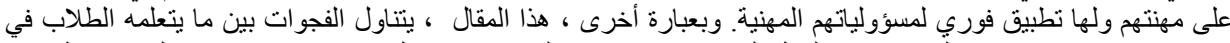

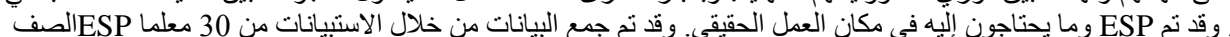

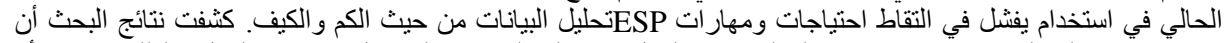

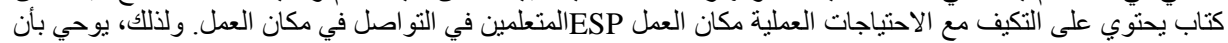

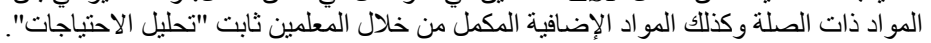

الكلمات الرئيسية: واقعي ، تحليل الاحتياجات، الدر اسات التجارية، مكان العمل، فعال ، التو اصل بين الثقافات 